Section Editor

Mitchell S.V. Elkind, MD, MS

Miguel E. Delgado, MD Oscar H. Del Brutto, MD

Correspondence \& reprint requests to Dr. Del Brutto: oscardelbrutto@hotmail.com

\title{
Teaching NeuroImages: Gradenigo syndrome
}

\section{Figure 1 Photograph of the patient shows isolated right abducens palsy}

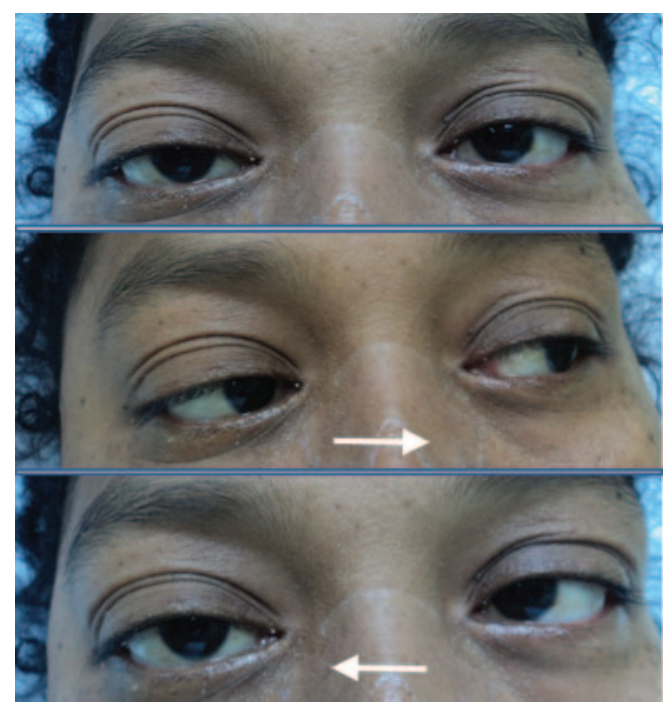

A 28-year-old woman presented with fever, double vision, and facial pain. Neurologic examination showed neck stiffness, pain in the distribution of the right trigeminal nerve, and right abducens palsy (figure 1). Tympanic membranes were normal. MRI revealed sphenoid sinusitis, basilar pachymeningitis, and clivus osteomyelitis (figure 2). CSF analysis showed pleocytosis, increased protein contents, decreased glucose levels, and positive cultures for Staphylococcus aureus. The triad of suppurative otitis media, pain in the distribution of the trigeminal nerve, and abducens palsy is called Gradenigo syndrome. ${ }^{1}$ While it most often affects children, it may occur in adults and may rarely present without otitis media. ${ }^{2}$ While bone compromise is usually confined to the
Figure 2 Head MRI
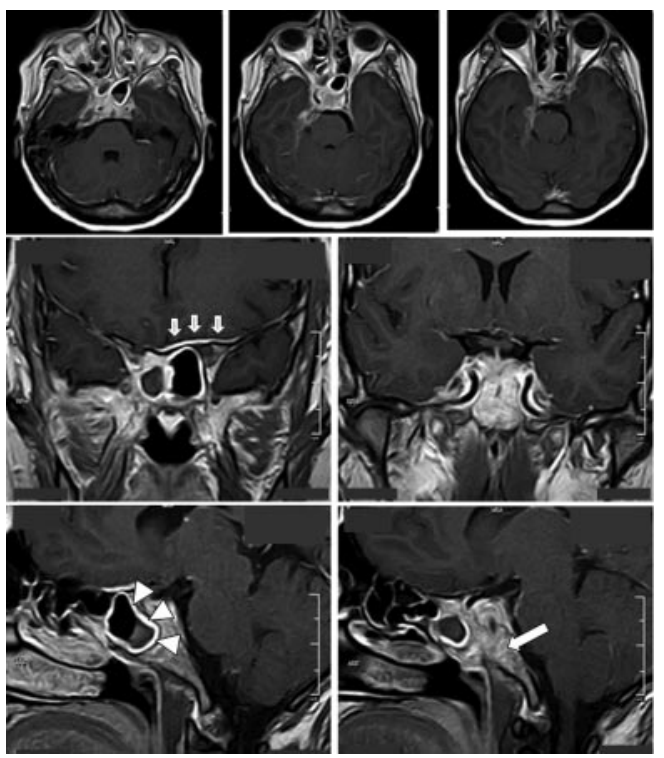

Contrast-enhanced T1-weighted MRI of the head shows mucosal thickening of sphenoid sinuses (arrowheads), basilar and right middle fossa pachymeningitis (small arrows), and osteomyelitis of the clivus (large arrow). While the right abducens nerve is not well visualized, it could be inferred in the axial sections (upper row) that it is entrapped throughout the Dorello channel and the cavernous sinus.

petrous apex, it may extend to sphenoid sinuses, clivus, and basal meninges.

\section{REFERENCE}

1. Motamed M, Kalan A. Gradenigo's syndrome. Postgrad Med J 2000;76:559-560.

2. Gibier L, Darrouzet V, Franco-Vidal V. Gradenigo syndrome without acute otitis media. Pediatr Neurol 2009; 41:215-219. 


\title{
Neurology
}

\author{
Teaching NeuroImages: Gradenigo syndrome \\ Miguel E. Delgado and Oscar H. Del Brutto \\ Neurology 2012;79; 141 \\ DOI 10.1212/WNL.0b013e31826e9b89
}

This information is current as of October 15, 2012

\section{Updated Information \& Services}

\section{References}

Subspecialty Collections

Permissions \& Licensing

Reprints including high resolution figures, can be found at: http://n.neurology.org/content/79/16/e141.full

This article cites 2 articles, 1 of which you can access for free at: http://n.neurology.org/content/79/16/e141.full\#ref-list-1

This article, along with others on similar topics, appears in the following collection(s):

Bacterial infections

http://n.neurology.org/cgi/collection/bacterial_infections

Diplopia (double vision)

http://n.neurology.org/cgi/collection/diplopia_double_vision

MRI

http://n.neurology.org/cgi/collection/mri

Ocular motility

http://n.neurology.org/cgi/collection/ocular_motility

Information about reproducing this article in parts (figures,tables) or in its entirety can be found online at:

http://www.neurology.org/about/about_the_journal\#permissions

Information about ordering reprints can be found online:

http://n.neurology.org/subscribers/advertise

Neurology ${ }^{\circledR}$ is the official journal of the American Academy of Neurology. Published continuously since 1951, it is now a weekly with 48 issues per year. Copyright Copyright @ 2012 by AAN Enterprises, Inc.. All rights reserved. Print ISSN: 0028-3878. Online ISSN: 1526-632X.

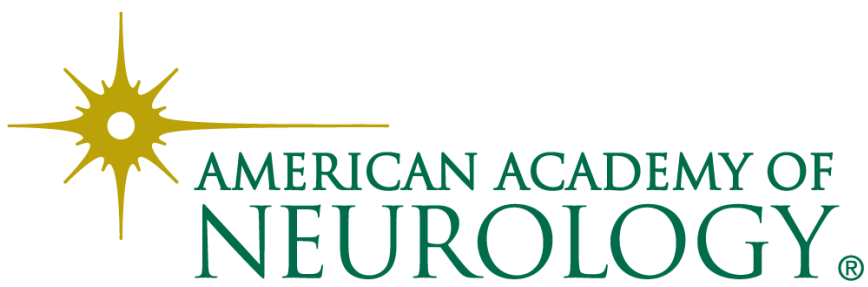

